\title{
ANAIYSIS OF ENTERPRISES AT ROMANIAN LEVEL
}

\author{
Bogdan CHIRIPUCI ${ }^{\mathrm{a} *}$ \\ a) Bucharest University of Economic Studies, Faculty of Agricultural and \\ Environmental Economics, Bucharest, Romania
}

Please cite this article as:

Article History:

Chiripuci, B., 2020. Analysis of enterprises at Romanian level. Review of Economic Studies and Received: 28 January 2020 Research Virgil Madgearu, 13(1), pp.5-31. doi: 10.24193/RVM.2020.13.49.

\begin{abstract}
The purpose of this research is to make a radiography on the number of enterprises at the Romania, which can represent a first step regarding the entrepreneurial development of the rural and practical environment, the increase of the number of companies in this area. In this sense, based on the data obtained from the National Trade Register Office, both a differentiation between urban and rural areas was made, as well as a classification of the type of enterprise existing at the level of Romania. All these have the role of identifying the difference between the two living environments, but also of observing a statistical evolution at national level regarding the development of each region separately. It was found that microenterprises have register the highest number regarding the type of enterprise existing on the Romanian territory. The reported value of these types of legal entities is 2-3 times higher in the urban area, compared to the rural area. Moreover, large enterprises have been found to be specific to the urban environment, as in the rural area there are registered in some regions of the country's development even a $10 \%$ percentage compared to the urban area.
\end{abstract}

Key words: enterprise; urban area; rural area; entrepreneur; economy JEL Classification: $\mathrm{F} 63$; $M 1 O$; O1O; R11

(C) 2020 Alma Mater Publishing House. All rights reserved.

* Corresponding author. E-mail address: bogdan.chiripuci@gmail.com. 


\section{References:}

1. Bosshard, A., 2000. A methodology and terminology of sustainability assessment and its perspectives for rural planning. Agriculture, Ecosystems \& Environment, 77(1-2), pp.29-41. https://doi. org/10.1016/So167-8809(99)00090-0.

2. Crosby, R.A., Wendel, M.L., Vanderpool, R.C. and Cassey, B.R., 2012. Rural Populations and Health: Determinants, Disparities and Solutions. San Francisco: Jossey-Bass.

3. Davidescu, A.A., 2014. Investigating the impact of unemployment rate on the Romanian shadow economy. A complex approach based on ARDL and SVAR analysis. Romanian Journal of Economic Forecasting, 17(4), pp.109-127.

4. Food and Agriculture Organization of the United Nations, 2016. Incorporating decent rural employment in the strategic planning for agricultural development. [pdf] Available at: <http://www.fao. org/3/a-i5471e.pdf> [Accessed 16.12.2019].

5. Lambin, E.F. and Meyfroidt, P., 2011. Global land use change, economic globalization, and the looming land scarcity. Proceedings of the National Academy of Sciences of the United States of America, 108(9), pp.3465-3472. https://doi.org/10.1073/pnas.1100480108.

6. Ministerul Agriculturii și Dezvoltării Rurale, 2012. Analiza socioeconomică în perspectiva dezvoltării rurale 2014-2020. [pdf] Available at: <http://www.madr.ro/docs/dezvoltare-rurala/ programare-2014-2020/analiza-dezvoltarii-rurale-agriculturaiulie-2013.pdf $>$ [Accessed 05.12.2020].

7. National register of the trade register from Romania (ONRC). Bucharest.

8. Popescu, A., Deaconu A. and Popescu T., 2014. The impact of gender difference at Romanian small and medium enterprises (SME) management level, analyzed by organizational citizenship behavior (OCB) lens. Procedia Economics and Finance, 8, pp.563-569. 10.1016/S2212-5671(14)00129-4. 